\title{
Nationalization and Personalization of the Egyptian Antiquities: Henry Salt a British General Consul in Egypt 1816 to 1827
}

\author{
Dr. Shadia Mahmoud (Corresponding author) \\ Director General of the Department \\ of the International Organizations for Culture Heritage \\ Ministry of Antiquities \\ Egypt \\ E-mail:mahmoud.shadia@gmail.com
}

Received: July 13, 2016 Accepted: September 29, 2016 Published: December 23, 2016

doi:10.5296/ijch.v3i2.7357 URL: http://dx.doi.org/10.5296/ijch.v3i2.7357

In 1998, an anthropologist, Philip L. Kohl stated that archaeological findings are manipulated for nationalist purposes and that archaeology's development during the nineteenth and twentieth centuries is associated with nationalism, colonization, imperialism, sometimes personal in Europe. ${ }^{1}$ Kohl's statement is significant because it conveys how archaeology emerged as a national mission. During the eighteenth, nineteenth, and twentieth centuries, Egyptian antiquities were at the center attention. Mythical and historical evidence for Greeks and Romans in Egypt were cited in order to justify the extensive excavations which were linked to a rising European national self consciousness. Consequently, the great imperialist powers, France and the Great Britain (who saw themselves as heirs of the Greeks and Romans) were determined to fulfill their national museum with the Egyptian antiquities.

Conventional histories of Egyptology have concentrated on a small number of important figures: the founding fathers whose scientific efforts laid the foundation for the discipline of Egyptology and whose collecting procedure enriched their national collections. However, focusing on a few persons diminishes the contribution of other individuals in the field who assisted in accomplishing their nation's objective. Henry Salt was sent on a national mission to fulfill British Museum collections and assist his country in standing against its famous

\footnotetext{
${ }^{1}$ Philip L. Kohl, "Nationalism and Archaeology: On the Constructions of Nations and the Reconstructions of the Remote Past," in Annual Review of Anthropology, Vol. 27 (1998), p. 223. Pp. 223-246
} 
rival (France). In his first four years, Mr. Salt focused on fulfilling his national mission. However, when his national mission conflicted with his personal ambitions, Salt disregarded his country's mission and sought after his own. This paper will explore Henry Salt correspondences to and from the British authority in order to illuminate how nationalism is modified and sometimes melted by the individuals' self interest in archaeology.

Henry Salt the son of Thomas Salt, a doctor, was trying to succeed as a portrait painter, but he did not do well in this area. After his failure as a painter, in 1805, Salt had had an opportunity to explore the African continent with Viscount Valentia, an English nobleman. In a letter to Valentia, Charles Salt, Henry Salt's brother, who was a close friend of Valentia and the one who recommended him wrote the following:

"These few lines may be all that I can send you before your departure, my ever dear friend. God bless and preserve you, and reward you for your heart-warm goodness to my beloved brother, who is the companion and friend of your voyage. You will have raised him at once from a sea of difficulties, and given him a fair and noble chance in life. $^{2}$

This trip inspired Mr. Salt's talent as a painter providing him with a chance to visit Egypt which in turn helped him learn how to use colors. Valentia was pleased with Mr. Salt's progress; therefore, he wrote to his friend J. J. Halls "I have the pleasure to inform you that he [Salt] gets on better than I expected, and I have no doubt that when he becomes acquainted with water-colors his drawings will be superior to my hopes."3 Mr. Salt succeeded in doing a number of sketches and published them on his own.

After his return from the second trip to Abyssinia and the success he achieved, Mr. Salt became a member of the British and Foreign Bible Society which assist the people of that country with copies of the Scriptures. ${ }^{4}$ When Mr. Salt returned back to England, he was looking forward to go back to Egypt. On April $13^{\text {th }} 1815$, Mr. Salt sent to Valentia the following letter expressing his joy at learning that Major Misset, the Consul-General in Egypt had resigned. Therefore, Mr. Salt addressed his desire to Sir William Hamilton, the president of Antiquarian Society, who "promised immediately to write in salt's favor, to Lord Castlereagh, urging his claims, which Sir William admitted 'were undoubtedly such as would entitle me to the situation, if no private patronage interfered."

In addition to Salt's desire to be in Egypt and at the archaeological sites there, this communication shows how this position was appointed according to personal favoritism. In Egypt, Mr. Salt's major was not just painting but also included to include collecting, publishing, and an interest in trading.

\footnotetext{
${ }^{2}$ Charles Salt to Viscount Valentia, May $24^{\text {th }} 1802$ in J. J. Halls, The Life and Correspondence of Henry Salt, ESQ. F. R. S. \& c.: His Majesty's Late Consul General in Egypt, in two volumes, Vol. 1 (London: Samuel Dentley Publisher, 1834)

3 Viscount Valentia to J. J. Halls October $19^{\text {th }} 1802$ in Halls, Vol. 1, 76

${ }^{4}$ From Mr. Salt's letter to Alexander Murray March $17^{\text {th }} 1812$ in Halls, Vol. 1, 322

${ }^{5}$ Henry Salt to Viscount Valentia, April $13^{\text {th }} 1815$ in Halls, Vol. 1, 322
} 
Upon his appointment as Consul General, Salt was required by the trustee of the British museum to procure the Egyptian antiquities for the national collections. Furthermore, the British Foreign Office urged Salt to search for another "Rosetta Stone ... [for] the enlightened nation ... which was eager to anticipate 'its rivals' in the prosecution of the best interest of science and literature." ${ }^{\prime \prime}$ As a result, Mr. Salt determined to operate extensive excavations to acquire antiquities for the British Museum and in the process amassed enormous quantities in his own account. In spite of his national task, Mr. Salt's intensive collecting activities brought him into enmity with his British counterparts.

Although possessed a good reputation through his important excavations in Thebes (Luxor) and in the pyramids, there were few sources that survived from his time. The most important work was done by J. J. Halls in 1834 in two volumes, seven years after Salt's sudden death. Halls includes all the letters Salt had sent to his friends and colleagues. In 1915, H. R. Hall published Salt's letter to Sir William Gell. C. E. Bosworth in 1977 provides in his paper Al-Jabarti and the Frankish Archaeologists, al-Jabarti's record of Salt, Burckhardt, Belzoni, and Caviglia's activities Upper and Lower Egypt's archaeological sites. Al-Jabarti was living in the same period as Salt. In 2001, Deborah Manley and Peta Ree offer an important biography of Salt through the investigation of his own letters to his friends. These letters revealed Salt's relationship with his friends, the Egyptian authorities, European collectors, and the trustee of the British museum. Strong leadership and extreme interest in the Egyptian archaeology served as a vital component of the British management in Egypt, and in this vein a collector such as Henry Salt was well qualified. ${ }^{7}$

On March 1816, Salt arrived in Alexandria, Egypt, where he was welcomed by the departing British Consul, Misset and Mr. Lee, the Levant Company's consul. Salt then wrote a letter to his friend Halls informing him that "the town [Alexandria] is so crowded with Europeans that it is not possible to hire a house of any kind, or even a room for a temporary occupation." ${ }^{\text {" A }}$ few days later, he started his work as British Consul-General. During Salt's consulship, Egypt was ruled by the Macedonian-Albanian, Mohamed Ali (in some books Mehemet Ali). After defeating the Mamluks, Mohamed Ali announced himself, as a ruler of Egypt. He gained the friendship of the religious authority which appointed him the title "Pasha". Being a representative of the British King in Egypt, Salt expected to possess unrestricted power to pursue his interest in the monuments and antiquities of Egypt. However, having heard about Mohamed Ali's personality, Salt was convinced that ... [it would] become more difficult to

\footnotetext{
${ }^{6}$ Brian M. Fagan, The Rape of the Nile: Tomb Robbers, Tourists, and Archaeological in Egypt (New York: Charles Scribner's Sons, 1975) 90

7 J. J. Halls, The Life and Correspondence of Henry Salt, ESQ. F. R. S. \& c.: His Majesty's Late Consul General in Egypt, in two volumes, Vol. 1 \& Vol. 2 (London: Samuel Dentley Publisher, 1834)

H. R. Hall, "Letters to Sir William Gell from Henry Salt, <Sir $>$ J. G. Wilkinson, and Baron von Bunsen; with preface," in the Journal of Egyptian Archaeology, Vol. 2, (1915).

C. E. Bosworth, "Al-Jabarti and the Frankish Archaeologists," in International Journal of Middle East Studies, Vol. 8, No. 2. (Apr., 1977)

Deborah Manley and Peta Ree, Henry Salt: Artist, Traveler, Diplomat, Egyptologist (London: Libri Press, 2001)

${ }^{8}$ Mr. Salt to Sir William Hamilton March $27^{\text {th }} 1816$ in Halls, Vol. 1452
} 
treat with [the Pasha, who] ... [would not] pay attention to the rights of European nations."9 Thus, the British assumed definite status in Egypt. This status was tied to their scientific superiority which justified their excavations in the Egyptian archaeological sites. In this regard, Edward Said cited in his book Orientalism a quote by Arthur James Balfour "is it a good thing for these nations - I admit their greatness - that this absolute government should be exercised by us? I think it is a good thing." 10 However, Mr. Salt's preceding statement contradicted with his following action. Mr. Salt would try to obtain the Pasha's satisfaction so that he would avoid any further problems.

As a result, Mr. Salt asked his partner in the excavations field, Bernard Lewis Burckhardt ${ }^{11}$, who was a friend of the Pasha, to accompany him in both private and public visit. The Pasha warmly received Mr. Salt and gave him a noble present and in turn, Mr. Salt offered the Pasha "cut glassware in silver stands and guns to his sons". ${ }^{2}$ For Salt, a good relationship with the Pasha would make his excavations easier. The Pasha, on the other hand, was looking for permission from Great Britain to have a small navy in the Red Sea. Thus, Salt acted as a mediator between the Great Britain's authorities and Mohamed Ali. He sent a letter to Sir William Hamilton, ESQ addressing the Pasha's request" to have his corvettes being permitted round the Cape of Good Hope into the Red Sea. Although Mr. Salt felt anxious, he urged Sir Hamilton to consider this permission, since this permission would aid Salt in accomplishing "British interests" in Egypt. ${ }^{13}$ On this occasion, Mr. Salt wrote as a British nationalist who sought advantages for his nation's objective. However, when Mr. Salt's personal interests came over his nation's mission he forwarded the following letter to his previous patron, Valentia informing him about the Pasha's request which Mr. Salt believed "could do no possible harm." Thus, Mr. Salt would ask the British government to give him a permission to "grant the Pasha the passport" without the government direct interfering. This absolutely would have the Pasha satisfied. Unless, I received the passport, I should tempt "to give the passport on my own responsibility.", 14

It was not clear from Mr. Salt's correspondences whether the Pasha was obtained through the passport for his navy or not. However, it could be inferred that he did receive the permission as Mr. Salt was possessed by a special position in the Pasha's court and was given a new house in the Frankish ${ }^{15}$ quarter, which was the main street in Cairo and inhabited by the British citizens. Mr. Salt referred to this house in his letter to Mr. Valentia "the Pasha granted

\footnotetext{
${ }^{9}$ Deborah Manley and Peta Ree, Henry Salt: Artist, Traveler, Diplomat, Egyptologist (London: Libri Press, 2001) 69

10 Edward Said, Orientalism (New York, Pantheon Books, 1978) 33

${ }^{11}$ He was British traveler whose interest in Egypt led him to convert to Islam and obtain an Islamic name, "Ibrahim al-Mahdia al-englizi".

12 Manley and Ree, 70

13 Mr. Salt to Sir William Hamilton June $18^{\text {th }} 1816$ in Halls, Vol. 1, 458

14 Mr. Salt to Sir William Hamilton December $28^{\text {th }} 1816$ in Halls, Vol. 1, 466

15 The name is derived from the "Franks" the Germanic tribes who dominated the Eastern Europe during the $16^{\text {th }}$ century. After the capture of Gaul, the term meant the freeman. Arab and modern historians call Western Europeans Frankish regardless of their country of origin.
} 
me "a house for my residence." 16

However, Salt's ambition was more than just a house. In the letter to Mr. Valentia, Salt asserted that "the only solace of existence" in "most wretched Egypt" was his hope of achieving financial wealth, which he repeatedly saw to be in the antiquities market. ${ }^{17}$ Consequently, a few days after his arrival to Egypt, Salt began his work in Sai el Haggar, the capital of Egypt during the $26^{\text {th }}$ dynasty. In later letter to Mr. Valentia who was honored the title of the Earl of Mountnorris, Mr. Salt expressed his joy from the discoveries he achieved, notifying him that "in short time he will receive from him description of antiquities, which he collected for Mountnorris' museum." 18 Valentia or Lord Mountnoirs asked Mr. Salt before his travel to Egypt to collect Egyptian antiquities for his own museum at Arley Hall including mummies, coins for his son, and seeds. Mr. Salt also included in his preceding letter that "Mountnorris would receive also coins for Lord Valentia. ${ }^{19}$ Lord Mountnorris was delighted with Mr. Salt's achievement and appreciated Mr. Salt's souvenirs. Salt also promised to send the seeds next time, but he would not be able to send the mummies as no ship would accept to carry them. The patronage relationship was very important during that time; therefore, Mr. Salt would try all the time to satisfy Lord Mountnoirs who had a great influence on the British authority.

During that time Egypt was suffering from plague that spread throughout the country and caused the death and the sickness among thousands of people. Although this was a disastrous time for Egyptian, it marked Mr. Salt's fortune in easily obtaining antiquities. In this regard, Mr. Salt forwarded a message to Mountnorris stating "for some time after my arrival, owing to the plague, I met with no antiques, which are becoming difficult to purchase; and I found that Monsieur Drovetti, the quondam French Consul, was in upper Egypt, buying up everything there to complete a collection upon which he has been engaged some years." 20 Later Drovetti would become the competitor in the field of excavations. Salt enjoyed all the advantages in Egypt and would in short time achieve more than he would have imagined. He suddenly found many people surrounding, appreciating his work, and seeking his friendship. However, Mr. Salt was smart in trying to keep attaching to the important people in the British society. On December $28^{\text {th }} 1816$, Mr. Salt wrote to Lord Mountnorris expressing his happiness being in Egypt, where "he noted that he felt "remarkably well, much better than in England" and that while grown thin he had "lost all his stomach complaints." 21 It was well known that foreigners appreciated Egypt weather and food which would relieve most of their health problems. In addition, Mr. Salt as a British Consul possessed all luxuries that he never could have had in England. In his letter to Lord Mountnorris, Mr. Salt described the house, which he was obtained from the Pasha as "irregular" consisted of many rooms connected

\footnotetext{
${ }^{16} \mathrm{Mr}$. Salt to Mr. Valentia December $28^{\text {th }} 1816$ in Halls, Vol. 1, 467

${ }^{17} \mathrm{Mr}$. Salt to Lord Mountnorris June $1^{\text {st }} 1819$ in Halls, Vol. 1, 500

${ }^{18} \mathrm{Mr}$. Salt to Valentia October $30^{\text {th }} 1816$ in Halls, Vol. 1, 464

${ }^{19}$ Ibid, 464

${ }^{20}$ Mr. Salt to Lord Valentia December $28^{\text {th }} 1816$ in Halls, Vol. 1, 472

${ }^{21}$ Ibid, 473
} 
with "two large salles." It also included library. The house was looking on "really respectably sized garden." I have had "three horses, two janissaries, a steward cook, two footman, and a gardener; a camel to fetch water from the Nile; a saqqia or water-carrier; a bourique, or jackass, for odd jobs; a bullock, for the garden and mill, and a washerwoman.",22

After finishing his excavation in Sai el Hagar, Salt determined to decode the inscription included on the column that he excavated in Sai el Hagar. Salt was a painter who financed the excavators to gather valuable collections for his nation. However, Salt modified himself to be an interpreter or archaeologist. He announced this news to Lord Mountnorris in a detailed letter that concluded a copy of the inscription on the column with the interpretation applied by Mr. Salt, which he believed "the name of perfect." At the same time, Mr. Salt forwarded to Sir William Hamilton, who was the president of the Antiquarian Society. Mr. Salt also informed Lord Mountnorris that "the French institute did me the honor of choosing me one of their foreign correspondents." ${ }^{23}$ In addition to his claim of being interpreter, Salt's letter reveals the emergence of his personal interest as he started to deal with the rival of his nation in the Egyptian field. Six years later, Mr. Salt went too far when he decided to challenge the archaeologists who preceded him in particular Thomas Young, a British scientist, who was involving in different fields including Egyptology. Young studied French, Italian, Hebrew, Syriac, Samarian, Arabic, Persian, Turkish, Amharic, and was one of the first scientists who tried to decipher the Egyptian hieroglyphs even before Jean Francois Champollion. Without a doubt Young was qualified enough and credited for his attempts. Mr. Salt, on the other hand, had painting as his only background and did not claim to have more than this. He gained his first experience with the Egyptian archaeology during his first trip with Mr. Valentia in 1805. In spite to all the previous facts, Salt tried to be part of the Egyptological science professions. $^{24}$ In that time, the field of the Egyptological studies was still a controversial one although they were many explorers who specialized in this field. In a letter addressed to Sir J. G. Wilkinson on September $16^{\text {th }}, 1822$, Salt declared his new discovery concerning the hieroglyphic characters and numbers where he disagreed with the English pioneer in archaeology, Thomas Young. While Young had argued that the characters that distinguish the dynasty of the Ptolemies represent the name of Ptolemy, Salt assigned them to the name of the first founder of the Greek dynasty. ${ }^{25}$ However, Salt mentioned that Alexander was the first founder of the Greek dynasty which indicated the misinterpretation of the archaeological and historical facts by such explorers. However, Wilkinson, who mentioned another incident in his letter to Sir William Gell declared that "Salt's list of kings Pharaoon, is all wrong, and I (Wilkinson Gell) not one in its place." 26 In this incident, Mr. Salt's assertion better fit the western ideology in linking the Egyptian culture to Greece. In addition, Egyptian archaeology

\footnotetext{
22 Mr. Salt to Lord Valentia December $28^{\text {th }} 1816$ in Halls, Vol. 1, 468

23 Mr. Salt to Lord Valentia December $28^{\text {th }} 1816$ in Halls, Vol. 1, 474

${ }^{24}$ Henry Salt to Sir William Gell September $16^{\text {th }} 1822$ in H. R. Hall, "Letters to Sir William Gell from Henry Salt, <Sir> J. G. Wilkinson, and Baron von Bunsen; with preface," in the Journal of Egyptian Archaeology, Vol. 2, (1915).

25 Hall, 139.

26 Ibid, 142.
} 
as a field of study had emerged during that time and moved from just collecting exotic antiques to the study and interpretation of hieroglyphic. Thus, Mr. Salt was willing to contribute to this field of study which would make his name known.

The desire of Europeans to promote themselves through Egyptian field often resulted in the disregard of other people's contribution to this field long before. One of these contributions was Ahmed Bin Abubekr Ibn Wahshiyah, who left an incomplete book which was handwritten by him including his attempts in decoding the ancient Egyptian scripts. According to Okasha El Daly, Ibn Wahshiyah's work was translated into English by J. Hammer in 1806. However, French scholars such as R. Sole and D. Valbelle disregarded Ibn Wahshiyah' work and considered Hommer's translation "the English contribution to the process of the decipherment progress without any mention to the original Arab author". ${ }^{27}$

As the field of Egyptian archaeology history evolved, studies that documented the importance of the medieval Arabs in the ancient Egyptian history and scripts were developed by historians such as J. Jakeman and J. Hammer. Through theirs and other historians' groundbreaking work, Egyptology scholarship shifted from stories of powerful contributors to a celebration of Champollion and Kircher's works, which blocked the way for an individual like Ibn Wahshiyah, Ayub Ibn Maslama, and Abu Al-Qasim Al-Iraqi to regain the historical recognition they so earned through their hard work and dedication to the ancient Egyptian history and scripts. As El Daly stated in re-examining the works of Kircher and Hammer, the writings of Ibn Wahshiyah and the other Arab historians may have been a source used by later Europeans attempting to give translations of various ancient texts. ${ }^{28}$

In one sense, the silence about the contribution of Ibn Wahshiyah is not unlike what happened to the work of Frank Calvert. Susan Heuck Allen in 1999 reinvestigates the discovery of the ruined walls of Troy at Hisarlik in modern Turkey and concludes that the archaeologist Heinrich Schliemann was not the one who discovered the Troy treasures as he claimed. Instead "Schliemann's self-aggrandizement cast into the shadows a man whose claim to having discovered Troy is just as strong, if not stronger: Frank Calvert". ${ }^{29}$ Calvert was unfortunate to publish his identification and discoveries of Troy as his financial crisis did not support him. He therefore contacted Schliemann, showed him his discovery, and asked him to dig in Hisarlik where the Troy ruins are located. However, Schliemann disregarded Calvert's own discovery and he assigned it to himself with Calvert's suggestion and advice. Thus, the parallelism between the Troy discovery and the hieroglyphic decipherment is clear. Both Ibn Wahshiyah and Calvert were unfortunate to publish their works. However, Ibn Wahshiyah's case, as El Daly states, needs an enormous amount of research to be authoritatively confirmed. $^{30}$

\footnotetext{
${ }^{27}$ Okasha El Daly, Egyptology: The Missing Millennium Ancient Egypt in Medieval Arabic Writings (London: UCL Press, 2005) 69.

28 El Daly, 69

29 Susan Heuck Allen, Finding the Walls of Troy: Frank Calvert and Heinrich Schliemann at Hisarlik (Los Angeles, London: University of California Press, 1999) 3.

30 El Daly, 73
} 
Going back to Mr. Salt, who decided to accompany Sir Joseph Banks, a member of the society for hieroglyphic, to Upper Egypt to explore the region and the potential opportunities he would have. Upon his return, Mr. Salt employed Giovani Battista Belzoni, ${ }^{31}$ an Italian excavator, explorer, and adventurer who was recommended to him by his partner Burckhardt, to remove the gigantic head of the younger Memnon in Thebes. Mr. Beechey, a British citizen and a painter who Mr. Salt escorted on his way from England, drew the instructions for Belzoni to follow. Belzoni succeeded in unearthing the head and sent it to Alexandria to be shipped to England. The excavation made by Belzoni at Mr. Salt's expenses was announced in public and published with Mr. Salt's interpretation in the Quarterly Review in $1818 .^{32} \mathrm{Mr}$. Belzoni's reputation reached its peak after the publication; therefore, Lord Mountnorris sent a letter requiring information about Mr. Belzoni. This of course made Mr. Salt jealous and during his following years in Egypt would try to make his name well known among the scholars of archaeology. However, Mr. Salt could not announce his feeling and in his response to Lord Mountnorris, Mr. Salt praised Mr. Belzoni. Mr. Salt stated that "Mr. Belzoni was a Roman, "who once performed on the stage feats of strength," Mr. Belzoni's background embedded in machines, but because of his physical characters, he could manage with his workers to "remove objects of great bulk." He was also very intelligent.",33

Mr. Salt's letter was too long full of details about the work that had been done for him by Mr. Belzoni. He conducted also the excavation in Abu Simbel and the excavations of other collections including sarcophagus of white alabaster and several paintings. Mr. Salt concluded his letter stating that "Mr. Belzoni deserved the credit he received for his discoveries. I have no right to object because I was the just financer who would worry about "benefiting of these discoveries" and "the drawing I have already made. ${ }^{34}$

In the discovery of the head of Ramses II or as they called it during that time Memnon's head, Mr. Bernard Lewis Burckhardt was working with Mr. Salt as his partner. Mr. Burckhardt's experience in this field dated back to his first trip to Nubia and Egypt and he was responsible for guiding Mr. Belzoni and Mr. Salt to the antiques' location which he already had drawn. Burckhardt was settling in Egypt and converted to Islam with the name of Sheik Ibrahim. Natives of Egypt were the guides of Burckhardt after he became one of them. Undeniably, Belzoni accomplished a difficult task of removing this immense head to the banks of the Nile from which it transported to Alexander and then to British Museum, where it still is exhibited. In reporting the expenses of this excavation to Lord Mountnorris, Mr. Salt states that "after paying all expenses" for the head transportation and Sheik Ibrahim's part, I gave Mr. Belzoni "a present of two thousand piastres, then fifty pounds." Thus, the total expenses were "about fourteen thousand piastres, somewhat more perhaps." 35

\footnotetext{
31 Belzoni was an Italian excavator, explorer, and adventurer (1778-1823). For more details see Dawson and Uphill pages $23 \& 90$ and the Egyptian website http://www.touregypt.net/featurestories/egyptologists.htm.

${ }^{32}$ Mr. Salt to Lord Mountnoirs August $7^{\text {th }} 1818$ in Halls, Vol. 1, 492

33 Mr. Salt to Lord Mountnoirs August $7^{\text {th }} 1818$ in Halls, Vol. 1, 493

34 Mr. Salt to Lord Mountnoirs August $7^{\text {th }} 1818$ in Halls, Vol. 1, 495

${ }^{35}$ Mr. Salt to Lord Mountnorris August $7^{\text {th }} 1818$ in Halls, Vol. 1, 497
} 
Belzoni, with Burckhardt's assistance and drawing, continued his excavations in Thebes in particular at the Karnak Temple and the West Valley of the Kings. Belzoni began his excavations in Thebes, hiring Egyptian peasants to assist him. However, according to Belzoni "after working few days and making a little progress, [they] grew tired of their employment, declared that it was unlawful to labour during the feast of Rhamadan and finally left.",36 Belzoni's statement concerning the native people's reaction should not be considered more than a propaganda designed and associated with the imperialist ideology to prove that these native are not qualified for such hard work. Besides, Mr. Belzoni depended heavily on these natives work and guidance since 1816, so they suddenly became irresponsible. According to Belzoni, he had to ask Mr. Beechey's assistance and his British counterparts, who were in Egypt during that time, captains Irby and Mangles' assistance. ${ }^{37}$ Charles Leonard Irby and James Mangles were commanders in the Royal Navy. ${ }^{38}$ Irby and Mangles never received more than military education, which most likely contributed to their strained relationship with antiquities, but curiosity, increasing admiration of antiquities, and seeking employment's extension were the reason of their adventures into Africa. At that time, the British authority would encourage such commanders extending their service if they would travel to explore the African continent's antiquities, customs, and people.

Belzoni's teem was working at Karnak the French team with the chief Drovetti. In this regard, Donald P. Ryan in his article titled BA Portrait: Giovani Battista Belzoni" ${ }^{39}$ states, "It did not take long for Belzoni to become well acquainted with the nationalistic competition that was blatantly apparent between rival countries in their quest to collect the most, the best, Egyptian antiquities for their countries' collections." ${ }^{40}$ In his statement, Ryan tends to eliminate Mr. Belzoni from the excavation activities, which he was involving in and submit it to the Anglo-French competition. However, Ryan seems not aware of the excavations Mr. Belzoni managed on his own.

Controversy between the Europeans was not limited to the interpretation (as it is already stated in this paper) but it extended to the excavation. Disagreement was raised between Salt and Belzoni and ended with "the unworthy treatment Mr. Salt experienced from Mr. Belzoni and certainly display anything rather than a hostile disposition towards that individual.",41 Belzoni stated his objection concerning his payment through Mr. Salt. Therefore, he wrote in secret to Lord Mountnoirs reporting some information about Mr. Salt. In his response to Lord Mountnoirs, Mr. Salt was pleading Lord Mountnoirs to not accuse him without evidence.

\footnotetext{
${ }^{36}$ From a MS. Memorandum of Mr. Salt Vide Quarterly Review, 1818, John James Halls, The Life and Correspondence of Henry Salt, ESQ. F.R.S. \&c., Vol. II (London: Richard Bentley Press, 1834) 33-34

37 Ibid, 33-34

${ }^{38}$ Charles Leonard Irby and James Mangles traveled to Egypt, Nubia, Syria, and Asia Minor in 1816 and published their memoirs in a book titled, Travels in Egypt and Nubia, Syria, and Asia Minor (London: T. White and Co. Printers, 1823)

39 Donald P. Ryan, "BA Portrait: Giovani Battista Belzoni," in the Biblical Archaeologist, Vol. 49, No. 3 (Sep. 1986), pp. 133-138

40 Ryan, 134

${ }^{41}$ Halls, Vol. II, 1.
} 
Lord Mountnoirs indicted Mr. Salt for not sending to any of his friends his latest news. However, Mr. Salt stated that he wrote to Lord Castlereagh, the president of the British Foreign Office, but he did receive any response. Mr. Salt also asserted that he wrote to Lord Mountnoirs two letters in which he gave him "accounts of everything were interesting, from Thebes." 42 Mr. Salt's letter was very long in which he tried to justify his aches against Belzoni accusation. However, Mr. Salt did not provide dates or copies of his letters which he talked about. This may suggest that Because Mr. Salt advocated exclusive excavation and excessive on his own through his employment Mr. Belzoni, Giovanni D'Athanasi, who was a Greek know as Yanni, and later Captain Caviglia, Salt ideological principles often clashed with some of his employees in particular Belzoni, who was looking for self profit.

After short time, Mr. Salt sent a private letter (Mr. Salt used to send private letters with the important information which should not be seen by others) to Lord Mountnoirs informing him that he published his new excavations' analysis and that he achieved "good enough in this side and [he] would not let anything deter me to continue in publishing. I just found my future way." future goal was to honor himself. An earlier letter to Lord Mountnoirs, Mr. Salt reported that he sent to British Museum Ramses' head, and "seven statues, which will be a most valuable ornament to your [Lord Mountnoirs] future gallery." "However, later on, Mr. Salt began to store all the collections he excavated in his house. In this respect, Abd al-Rahman al-Jabarti, an Egyptian Arab historian, who was in contact with the Frankish archaeologists and the fruits of their collecting activities in Upper Egypt, recorded the activities of Salt, Burckhardt, Belzoni, and Caviglia. ${ }^{45}$ Between October $12^{\text {th }}$ and November $10^{\text {th }} 1817$, Al-Jabarti observed the English Franks' [Mr. Salt and his team] work in the Pyramids and the Upper Egypt. Al-Jabarti, who began in the early 1797 to record Napoleon's invasion, continuing as an eyewitness account to the Europeans excavation in Egypt. What Al-Jabarti had done was to document the history of Egypt during Mohamed Ali period, among which was Salt's monumental work to account for the cause and effect of events and trace them back to an economic and financial bases. Al-Jabarti noticed that some of individuals, including Mr. Salt, spent vast sums of money on provisions, hiring workmen, and protection. Since, the excavation's cost was very high, the Europeans targeted the valuable collections such as inscriptions, sarcophagi, mummies with their gilded masks, statues of kings and queens. Upon observing these activities, Al-Jabarti decided to go "along in the company of [his] ... son Shaykh Mustafa Bakir, known as al-Sa'ati, and my master Ibrahim al-Mahdi-al-Ingilizi [Burckhardt] to the house of one of the consuls in the Street of the Nubians (Darb al-Barabira) in the locality of the mound of Shaykh Salama in the direction of Uzbakiyya." ${ }^{46}$ Al-Jabarti here was referring to Henry Salt, who chose to leave in center of Cairo during that time which

\footnotetext{
${ }^{42}$ Mr. Salt to Lord Mountnoirs June 1, 1819 in Halls, vol. 1, 499

43 Mr. Salt to Lord Mountnoirs June 1, 1819 in Halls, vol. 1, 500

44 Mr. Salt to Lord Mountnoirs December $18^{\text {th }} 1816$ in Halls, Vol. II, 7

45 C. E. Bosworth, "Al-Jabarti and the Frankish Archaeologists," in International Journal of Middle East Studies, Vol. 8, No. 2. (Apr., 1977), pp. 229-236

46 Al-Jabarti meant Henry Salt.
} 
was almost inhabited by British. There, Al-Jabarti monitored incredible collections. The collections that Al-Jabarti observed were all acquired from the Upper Egypt. Salt then determined to examine the Pyramids district.

As Al-Jabarti indicated, the Franks took the inscribed granite table that located between the forepaws of the Sphinx and one statuette of lion which situated in each side of the Sphinx. Giovanni Battista Caviglia, ${ }^{47}$ an Italian master mariner, was the one who convinced Mr. Salt to work in the Pyramids and the Sphinx zones then Mr. Salt agreed to finance him. ${ }^{48}$ The work in the Sphinx was operated by Caviglia and his sailors which reveal the propaganda westerners designed to legitimize their dominance in the Mediterranean and the Middle East. There was no difference between the Egyptians and unqualified Europeans; rather, the Egyptian possessed knowledge of the ancient monuments' locations.

The relationship between Mr. Belzoni and Mr. Salt was not restored to their earlier times. In fact their enmity increased and they began to accuse each other in either the media [newspapers] or with the British authority. Thus, in his last letter, Mr. Salt explained to Lord Mountnoirs that "on November 1817, Mr. Belzoni began to complain about his salary and required a part from the whole returns, he [Mr. Belzoni concluded that "it was time to think of [his] own interests; he had worked long enough for others and desired know how [Mr. Salt] intended to remunerate him." 49 Thus, Mr. Belzoni started to think of gaining the fruitful of his excavation instead of getting salary as employee. Later in the same letter, Mr. Salt continued to describe Mr. Belzoni' sudden change in his attitude adding "Mr. Belzoni had been in my employ [;] he suddenly broke out in the most violent terms and declared, to my great astonishment, that he [Mr. Belzoni] had never been employed by me, that he had been working for the British Nation, (being the first time he had ever started such notion,) and that he would be satisfied to go without reward." 50 It could be perceived from this letter how those individuals tied their mission to the idea of nationalism. Mr. Belzoni became a British citizen after his marriage to an English woman. Mr. Belzoni during his time with Mr. Salt noticed the power he [Mr. Salt] possessed through the British Nation. Therefore, Mr. Belzoni decided to follow his counterpart's policy to ultimately reach his own goals. According to Donald Malcolm Reid, "behind the façade of international science Western Egyptology seethed with national rivalries. The Anglo-French Egyptology rivalry [I add here the Anglo-Anglo rivalry], which was bound up with the two powers' imperial ambitions in Egypt and the Eastern Mediterranean, spanned the nineteenth century and persisted well into the twentieth". 51

After the ending of Mr. Belzoni's episode, Mr. Salt resumed his collecting activities with

\footnotetext{
${ }^{47}$ He was the owner and master of a trading vessel in the Mediterranean and was hired by Salt and others to excavate the Great Sphinx. For more details see Dawson and Uphill page 56.

48 Donald Malcolm Reid, Whose Pharaohs? Archaeology, Museums, and Egyptian National Identity from Napoleon to World War I (Berkeley, Los Angeles, London: University of California Press, 2002) 236

49 Mr. Salt to Lord Mountnoirs June $1^{\text {st }} 1818$ in Halls, Vol. II, 14

${ }^{50}$ Mr. Salt to Lord Mountnoirs June $1^{\text {st }} 1818$ in Halls, vol. II, 14

51 Reid, 130
} 
Caviglia in the Pyramids. In his letter to Sir William Hamilton, ESQ, the office of Secretary to the African Association and the president of the Society for hieroglyphic, Mr. Salt reported his achievements stating "I would like to introduce to you my friend Mr. Briggs, ${ }^{52}$ who was the sharer with Caviglia and me in the work of the Pyramids. His long residence in Egypt, and great knowledge of the country, will enable him to give me any information you may wish to have respecting our affairs." ${ }^{, 53}$ It can be seen, when Mr. Salt determined to work for his own, he would hire and seek other people company. Yet, problem we encounter in all $\mathrm{Mr}$. Salt's letters is his neglect of the Egyptian workers who assisted and guided these explorers to the fruitful sites. Therefore, as Egyptian archaeology took root in western institutions and universities, the conventional view of the field focused on its success through the activism of dynamic British consuls, adventures, and collectors who increased the British Museum collections and only to lesser extent, the engagement of native workers who assisted in guiding and unearthing their archaeological sites.

Mr. Salt was one of several agents that the trustee of the British Museum depended on to obtain valuable collections of Egyptian antiquities. At first, the Egyptian collections were "collections of curiosities" which were unusual and bizarre; however, this view was changed when the museum's trustee defined ancient Egypt in terms of its relationship to the art of ancient Greece which was simultaneously appropriated as Western and dismissed as exotic. ${ }^{54}$ Westerners imagined themselves entering the world of the pharaohs, the Bible, the Greeks, and Romans. In this respect, Arthur James Balfour, a European writer pointed out that "we are in Egypt not merely for the sake of the Egyptians, though we are there for their sake; we are there also for the sake of Europe at large." 55 With this attitude, Mr. Salt had to modify himself from being just a collector to excavator and Egyptologist.

Thus, Mr. Salt invited Mr. Bankes to visit Egypt. Mr. Bankes was one of the members of the new Society for the Hieroglyphics established by Sir William Hamilton in England at that time. Mr. Salt in his letter to Lord Mountnoirs included that "Mr. Bankes and [Salt] have discovered, on the leg of one of the Colossi in front of the Temple of [Abu Simbel], a Greek inscription written in the time of Psammetichus [the Egyptian Pharaoh and the founder of the $26^{\text {th }}$ dynasty]. ${ }^{56}$ It will be noticed in Mr. Salt's letters that he would send different information to different people at the same time. He also sometime would address earlier information because of its connection with the recent ones. For example, On September $22^{\text {nd }}$, 1822, Mr. Salt wrote to Colonel Leake congratulating him for the Office of Secretary to the African Association. Mr. Salt used the occasion to bring up his disagreement with Mr. Belzoni and try to convince Colonel Leake that "Mr. Hamilton did mistake when he supported Mr. Belzoni accusation against me [Mr. Salt]. I therefore forwarded to you my

\footnotetext{
52 Samuel Briggs, the British Consul in Alexandria.

53 Mr. Salt to Mr. Hamilton May $4^{\text {th }} 1819$ in Halls, Vol. II, 114.

54 Stephanie Moser, Wondrous Curiosities: Ancient Egypt at the British Museum (Chicago \& London: The University of Chicago Press, 2006) 229.

55 Said, 33

56 Mr. Salt to Lord Mountnorris May $7^{\text {th }} 1819$ in Halls, Vol. II, 120
} 
memoir concerning Mr. Belzoni's claim. ${ }^{57}$ Mr. Belzoni claimed that the collection Mr. Salt had sent to the British Museum was belonging to him [Mr. Belzoni]. Mr. Hamilton, who was a close friend of Mr. Salt as it is stated through this paper, believed Mr. Belzoni's statement. Back to Mr. Salt and Mr. Bankes who worked together in Abu Simbel and Nubia and kept their contact with Sir Hamilton. Mr. Salt sent to Sir. William Hamilton informing him that he translated the hieroglyphic texts included in these excavations urging him "to be a subscriber to [his] society for hieroglyphic. Your first step [is to require] a complete and well-drawn set of hieroglyphics, which I think I could get done for you at no great expense." ${ }^{, 58}$ It should be stated here that Mr. Salt was eager to obtain both financial returns which it was already established and scientific fame. He started to seek this scientific reputation since his agreement with Belzoni and the good reputation the latter achieved through his excavation.

The field of Egyptology at that time was dominated and created by the Europeans starting with French, British, German, and finally Russians and Americans. On May $22^{\text {nd }} 1819$, Mr. Salt sent to Mrs. Bessy Morgan informing her that "the Baron Sack, Chamberlain to the King of Prussia, who was recommended by the British government, would work as excavator with him and would accompany him to Nubia "to examine the antiquities and make sketches of them." ${ }^{, 59}$ Mrs. Morgan his was Mr. Salt's sister.

Officially, Mr. Salt was selling all the antiquities he would collect to British Museum, but Mr. Salt had hidden treatment with either the individuals who possessed a private museum or they were planning to establish one. When he disagreed with British Museum that did not consider the efforts and the money Mr. Salt's consumed, he announced his activity in public. Thus, following the failure of the trustee of the British Museum to comply with Salt's ambitions, King of France bought Salt's second collection which had been reported by Champollion. ${ }^{60}$ In addition to this, Salt's third collection was sold in a seven days' sale to antiquarians and the British Museum. ${ }^{61}$ At that time, the market of antiquities was open to the highest bid. Thus, Mr. Salt's business expanded and he was requested by private museum to provide Egyptian antiquities. In his letter to Sir Francis Darwin, Mr. Salt expressed his apology for not sending the crocodile and other things Sir Darwin required and promised "[he] had procured [him] a noble specimen of the former at Thebes, stuffed and ready prepared and he should 'expect them soon down with a few mummies of animals, \&c. for your museum. ${ }^{62}$

During the years 1820 to 1826 , Henry Salt operated immersed excavation around Egypt in Thebes, Nubia, and Lower Egypt. Throughout this time, he was careful to keep his relationship with the British noblemen and the society of archaeology that was created around

\footnotetext{
${ }^{57}$ Mr. Salt to Colonel Leake on September $22^{\text {nd }} 1822$ in Halls, Vol. II, 210

58 Mr. Salt to Mr. Hamilton May $4^{\text {th }} 1819$ in Halls, Vol. II, 120.

${ }^{59}$ Mr. Salt to Mrs. Bessy Morgan May $22^{\text {nd }} 1819$ in Halls, Vol. II, 121-122

${ }^{60}$ Warren R. Dawson and Eric P. Uphill, Who Was Who in Egyptology: A Biographical Index of Egyptologists; of Travelers, Explorers, and Excavators in Egypt; of Collectors of and Dealers in Egyptian Antiquities; of Consuls, Officials, Authors, Benefactors, and others whose names occur in the Literature of Egyptology, from the year 1500 to present day, but excluding people now living (London: The Egypt Exploration Society, 1972) 258.

61 Dawson and Uphill, 258

${ }^{62}$ Mr. Salt to Mr. Francis Darwin June $2^{\text {nd }} 1819$ in Halls, Vol. II, 137
} 
1818 or 1819. Mr. Salt considered himself a fortunate man being in Egypt and expressed his feeling in a letter to his niece "You must know, that the Consuls "in these barbarous regions [including Egypt] are sort of Kings. Every Consulate here [Egypt] is a little Government. Thus, besides my office affairs, I spent my time "in poring over Greek manuscripts, and the study of Egyptian antiquities." ${ }^{\text {"63 }}$ However, Mr. Salt did not report to his niece the trade he was involved in. In his letter to his friend J. J. Halls, Mr. Salt stated that the "In Egypt, the trade in corn was enormous and the Pasha owned both Mediterranean and Red Sea vessels. "With such a man, I should think that a great deal may be done." ${ }^{64}$ However, in later letter to Sir William Hamilton, Mr. Salt reported this information in different way. He told Sir Hamilton that the trade in Egypt was flourishing. There were more than hundred ships in the port almost third of them under English color. ${ }^{65}$ This incident presented Mr. Salt' ambitions, that he could not express it in the public letter.

It is indicated earlier that Mr. Salt's relationship with the Trustee of the British Museum was deteriorated. However, Mr. Salt's relation with British Museum was restored around 1824 which means three years prior to his death. In later letter to his sister's husband, Mr. Richard, Mr. Salt expressed his pleasure because his "affair with the British Museum has turned better than [he] expected." He was delighted by the way "the Trustees have behaved shabbily enough through the whole transaction."

\section{Conclusion}

Throughout the eighteenth and nineteenth centuries, the Western countries, in particular the Great Britain and France foresaw the Egyptian archaeology as a national mission and personal goal. Henry Salt was a representative of such regime. Salt was considered of poorer quality comparing to his other seven brothers. This feeling deterred him of achieving any success in the field of art. However, his life was completely changed after his first trip to Africa and India with his lordship Viscount Valentia. In 1816, Mr. Salt was appointed to the position of the British Consul General in Egypt. Before traveling to Egypt, Mr. Salt was strongly encouraged to collect Egyptian antiquities for British Museum and they urged him to consider this task as a mission for the enlightened nation. Mr. Salt announced in public letter that he would fulfill the museum of his nation with the Egyptian antiquities.

The British's mission in Egypt was tied to the Anglo-French rivalry and so was justified. In this respect, Patricia M. E. Lorcin, in her article Rome and France in Africa: Recovering Colonial Algeria's Latin Past, concludes that "Napoleonic expedition was an initial step in creating the association between imperial France and imperial Rome in Africa. ${ }^{, 66}$ Thus, the Europeans claimed either the inheritance' legacy (like the French in Algeria), the rival's legitimation (like the British presence in South Africa), or scientific superiority (like the British in Egypt). Mr. Salt already had an interest in excavating the Egyptian antiquities since

\footnotetext{
${ }^{63}$ Mr. Salt to his niece September $2^{\text {nd }} 1822$ in Halls, Vol. II, 193, 197

${ }^{64}$ Mr. Salt to J. J. Halls on January $22^{\text {nd }}, 1816$ in Halls, Vol. 1, 445

${ }^{65}$ Mr. Salt to Sir William Hamilton in Halls, Vol. 1, 451

${ }^{66}$ Patricia M. E. Lorcin, "Rome and France in Africa: Recovering Colonial Algeria's Latin Past," in French Historical Studies, Spring2002, Vol. 25 Issue 2
} 
his first tour to Egypt. As it was previously indicated in this paper, Mr. Salt found in the Egyptian antiquities trade the key to easily make money. However, now it turned to be a national mission. In respect to Egyptology, Brian M. Fagan mentions that "the duties of the British and French consuls general were far from arduous. Both enjoyed considerable influence with the pasha, but the political issues were hardly of major importance". ${ }^{67}$

The desire of Europeans to promote themselves through Egyptian field often resulted in the loss of their shared discriminatory experiences with the several collections that they excavated. Mr. Belzoni was the first excavator Mr. Salt hired according to his partner Burckhardt's recommendation. Mr. Belzoni achieved a considerable job and helped Mr. Salt to fulfill his nation's objective. However, disagreement rose between the two men ended by their division. Mr. Belzoni tried to use the same propaganda Mr. Salt applied by connecting himself [Mr. Belzoni] to the British Nation. Although there was no indication in Mr. Salt's letter to the path of Mr. Belzoni, Ryan states that Belzoni was considered an archaeologist among British intellectual society and accomplished several exhibition with some collections he transported them when he departed from Egypt in $1819 .{ }^{68}$

After Mr. Belzoni, Mr. Salt employed Captain Caviglia, an excavator, Mr. Ricci, a painter to mention a few. Mr. Salt continued in providing British Museum with all the archaeological findings he encountered until finally he did not accept the price British Museum proposed for his excellent collections. Thus, Mr. Salt started to look for own mission.

This paper asserts the ideas of nationalism is adjusted with the individuals self interest. Mr. Salt began his activities as a British Nationalist who sought the richness and the dignity of his country. However, when his nation's proposal did not meet his expectation; he offered his collections to either Louvre Museum or private museums.

I conclude this paper by two questions: Was the difference between the Europeans collectors and the Egyptians based on scientific superiority in the field of Egyptology? After nationalizing the field of Egyptology, did the Egyptian prevent the plundering of their heritage?

\section{Copyright Disclaimer}

Copyright for this article is retained by the author(s), with first publication rights granted to the journal.

This is an open-access article distributed under the terms and conditions of the Creative Commons Attribution license (http://creativecommons.org/licenses/by/3.0/).

\footnotetext{
67 Fagan, 89

68 Ryan, 139
} 